\title{
Vitellogenesis and vitelline system in the pseudophyllidean tapeworm Paraechinophallus japonicus: ultrastructural and cytochemical studies
}

\author{
Céline Levron $^{1,2}$, Larisa G. Poddubnaya ${ }^{3}$, Roman Kuchta $^{1,4}$, Mark Freeman $^{5}$ and Tomáš Scholz ${ }^{1}$ \\ ${ }^{1}$ Institute of Parasitology, Biology Centre, Academy of Sciences of the Czech Republic, Branišovská 31, 37005 České \\ Budějovice, Czech Republic; \\ ${ }^{2}$ Laboratoire Parasites et Ecosystèmes Méditerranéens, Faculté des Sciences et Techniques, Université de Corse, Campus \\ Grossetti, 20250 Corte, France; \\ ${ }^{3}$ Institute of Biology of Inland Waters, Russian Academy of Sciences, 152742 Borok, Yaroslavl Province, Russia; \\ ${ }^{4}$ Faculty of Biological Sciences, University of South Bohemia, Branišovská 31, 37005 České Budějovice, Czech Republic; \\ ${ }^{5}$ Institute of Aquaculture, University of Stirling, Stirling, FK9 4LA, UK
}

Key words: Cestoda, Pseudophyllidea, Paraechinophallus japonicus, vitelline system, vitellogenesis, ultrastructure

\begin{abstract}
The vitellogenesis of Paraechinophallus japonicus (Yamaguti, 1934), the first pseudophyllidean tapeworm of the family Echinophallidae studied using transmission electron microscope, is described on the basis of ultrastructural observations of specimens from the benthopelagic fish Psenopsis anomala (Temminck et Schlegel, 1844) (Perciformes: Centrolophidae). The process of vitellogenesis in $P$. japonicus follows the same general pattern observed in other tapeworms. Five stages of vitellocyte development have been distinguished. The first stage corresponds to immature cells containing ribosomes and mitochondria. The second stage of development is characterized by the appearance of granular endoplasmic reticulum and Golgi complexes, formation of shell globules and lipid droplets at the periphery of the cell cytoplasm. Vitellocyte of the third stage presents accumulation of shell globules and lipid droplets. During the fourth stage, shell globule clusters are formed, and lipid droplets and rosettes of $\alpha$ glycogen are accumulated. Mature vitelline cells are characterized by a great number of lipid droplets with glycogen in the centre of the cytoplasm, whereas shell globule clusters are situated more peripherally. The interstitial tissue of vitelline follicles of $P$. japonicus is syncytial with long cytoplasmic projections extending between vitelline cells. The presence of a large amount of lipid droplets in the vitelline cytoplasm within the eggs of $P$. japonicus may be related to egg accumulation in the uterine sac.
\end{abstract}

The process of egg formation of parasitic flatworms (Neodermata) is characterized by participation of products of the ovary, testis and vitelline follicles. Tapeworms of the order Pseudophyllidea contain numerous vitelline follicles, because they produce a large number of polylecithal eggs that contain a single ovum and a large number of vitellocytes, enclosed by a thick eggshell. Approximately 30 vitelline cells are required for each complete formation of a pseudophyllidean egg (Świderski and Xylander 2000). Vitellocytes play two basic functions in cestode embryogenesis: formation of a hard egg-shell and supplying nutritive reserves for developing embryo (Świderski and Xylander 1998, 2000).

Despite the fact that vitellogenesis in different groups of cestodes has a common pattern, there are some differences in the amount of vitellocyte material, such as shell globule clusters, lipids and glycogen, and in the morphology of shell globule clusters, types of lipid droplets and localisation of these inclusions in the vitelline cytoplasm (Świderski and Mackiewicz 1976, Bru- ňanská 1997, Świderski and Xylander 1998, 2000, Świderski et al. 2000, 2004a, b, 2005a, 2006a, b, Bruňanská et al. 2005).

In the Pseudophyllidea, one of the basal groups of the Eucestoda, only two species have been investigated for vitellogenesis, namely Bothriocephalus clavibothrium (Bothriocephalidae) and Triaenophorus nodulosus (Triaenophoridae) (Świderski and Mokhtar 1974, Korneva 2001).

Paraechinophallus japonicus (Yamaguti, 1934) (Pseudophyllidea: Echinophallidae), a parasite of pyloric appendices of the benthopelagic fish Psenopsis anomala (Temminck et Schlegel, 1844), is an insufficiently known tapeworm with regard to the type of embryonic development, degree of oviparity and life cycle. The knowledge of vitellogenesis pattern and vitellocyte material, with particular attention paid to the type of granule inclusions within vitelline ducts and intrauterine eggs in $P$. japonicus, and comparison of these data with those in other cestode species may be useful for understanding of biology of this tapeworm. 


\section{MATERIALS AND METHODS}

Adult specimens of the tapeworm Paraechinophallus japonicus were obtained from the intestine of Psenopsis anomala (Perciformes: Centrolophidae), collected from an inland sea area in Japan, 2004 by one of the authors (M.F.). Living worms were rinsed in $0.9 \% \mathrm{NaCl}$ solution. Mature and gravid proglottids were separated and fixed with $2.5 \%$ glutaraldehyde in cacodylate buffer for one day, washed overnight in $0.1 \mathrm{M}$ sodium cacodylate buffer at $\mathrm{pH} 7.4$, postfixed in cold $\left(4^{\circ} \mathrm{C}\right) 1 \% \mathrm{OsO}_{4}$ in the same buffer for $1 \mathrm{~h}$, dehydrated in a graded series of acetone and embedded in Spurr's epoxy resin within beem capsules. Ultrathin sections $(60-90 \mathrm{~nm}$ in thickness) were cut on a Leica Ultracut UCT ultramicrotome, placed on copper grids and stained with uranyl acetate and lead citrate according to Reynolds (1963). Sections were examined in a JEOL 1010 transmission electron microscope operated at $80 \mathrm{kV}$.

The glycogen was detected using the periodic acid-thiosemicarbazide-silver proteinate (PA-TSC-SP), according to the method of Thiéry (1967).

\section{RESULTS}

Vitelline follicles of Paraechinophallus japonicus are numerous and situated in the cortical parenchyma. They are composed of cells at different stages of development (Fig. 1). Five stages of the development of vitelline cells can be recognized as described below.

Immature vitellocytes Figs. 1, 2, 16I

Immature vitellocytes of $P$. japonicus are elongated cells (around $5 \mu \mathrm{m}$ long) usually localised at the periphery of the follicle (Fig. 1). They are distinguished by a high nucleus/plasma ratio (1:2). The nucleus contains a large electron-dense nucleolus and dense areas of heterochromatin (Fig. 2). Many free ribosomes and few mitochondria are concentrated in the cytoplasm (Figs. 2, 16I).

\section{Early stages of maturation}

Figs. 3-5, 16IIA

This stage is characterized by the presence of long cisternae of granular endoplasmic reticulum (Figs. 3, 5, 16IIA). Golgi complexes are characterized by concentration of small vesicles with newly formed shell globules (Fig. 4). Different stages of formation of these shell globules can be observed. First, Golgi complexes produce small electron-translucent vesicles corresponding to the precursor of shell globules (Fig. 4). Subsequently, the vesicles, containing rounded shell globule material, increase in size (Fig. 4) and fuse. Single lipid inclusions may associate with concentric rows of the endoplasmic reticulum in the cytoplasm (Fig. 5). A few single shell globules within an electron-translucent vesicle and a few lipid droplets are visible (Fig. 3). The nucleus contains a nucleolus and heterochromatin (Fig. 3).

Middle stages of maturation

Figs. 6, 16IIB

This stage of vitellocyte development is characterized by increasing of both cytoplasm volume (around 10 $\mu \mathrm{m}$ long) and number of single shell globules and lipid droplets that are distributed throughout most of the cell cytoplasm (Figs. 6, 16IIB). Granular endoplasmic reticulum (GER), Golgi complexes and mitochondria occupy vitelline cytoplasm (Fig. 16IIB). This cell type presents also a large nucleus with a prominent nucleolus and irregular clumps of electron-dense heterochromatin (Fig. 6).

\section{Advanced stages of maturation $\quad$ Figs. 7-9, 16IIC}

The cytoplasmic volume increases, the diameter of the cell varies from 12 to $15 \mu \mathrm{m}$. Shell globule clusters are formed by fusion of vesicles containing single shell globules of various sizes. The clusters consist of units (two to eight) embedded in an electron-lucent matrix (Figs. 7, 9) and they are predominantly located at the peripheral region of the cell cytoplasm (Figs. 7, 16IIC). The method of Thiéry clearly reveals the presence of rosettes of $\alpha$-glycogen (Fig. 8). Lipid droplets are in close association with $\alpha$-glycogen (Fig. 9).

\section{Mature vitellocytes \\ Figs. 10, 11, 16III}

Mature vitellocytes are large cells (around $20 \mu \mathrm{m}$ long) with the nucleus containing a large nucleolus and situated close to the plasma membrane (Figs. 10, 16III). Cytoplasmic organelles (GER, Golgi complexes) are confined to the perinuclear region and cell periphery (Fig. 10). The central cytoplasm is filled with lipid droplets and glycogen. Shell globule clusters are usually closer to the peripheral areas of the cell cytoplasm (Figs. $10,11,16 \mathrm{III})$.

\section{Interstitial syncytium}

Figs. 11, 12

The interstitial tissue is syncytial and contains several nuclei with scattered electron-dense heterochromatin (Fig. 11). The cytoplasm of the interstitial syncytium forms long tree-like projections which extend between vitelline cells (Fig. 12) and are filled with vesicular inclusions (Figs. 11, 12).

Vitelline ducts

Figs. 13, 14

The epithelial wall of vitelline ducts is covered with cilia (Fig. 14). The cytoplasm of the duct epithelium contains numerous electron-translucent rounded vesicles (Fig. 14). Mature vitellocytes, with the nucleus, numerous lipid droplets, glycogen and shell globule clusters, are present within the vitelline duct lumen (Fig. 13).

\section{Intrauterine eggs}

Fig. 15

Within the uterine lumen, formed eggs contain a fertilized ovum surrounded by numerous vitelline cells (Fig. 15). The cytoplasm of these cells is characterized by numerous lipid droplets (Fig. 15).

\section{DISCUSSION}

Vitellogenesis in the tapeworm Paraechinophallus japonicus appears to follow the same general pattern as that described for the Eucestoda (Świderski and Xylander 2000), including pseudophyllidean species studied using TEM, namely Bothriocephalus clavibothrium and Triaenophorus nodulosus (Świderski and Mokhtar 


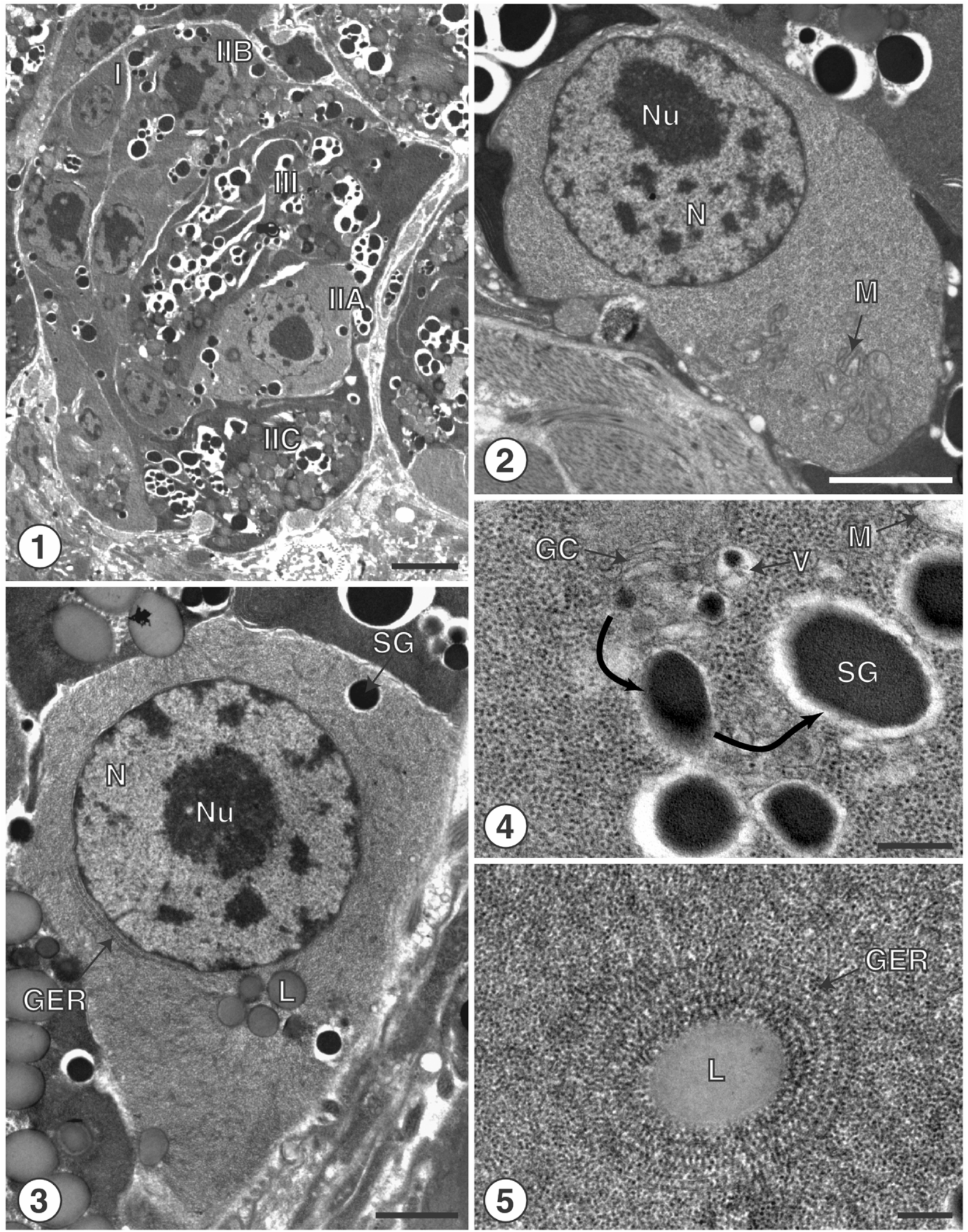

Figs. 1-5. Stages of vitellocyte development in vitellaria of Paraechinophallus japonicus. Fig. 1. Vitelline follicle showing vitellocytes at various stages of maturation. Fig. 2. Immature cell. Fig. 3. Early stage of maturation. Fig. 4. Golgi complex produces shell globules situated inside electron-lucent vacuoles. Fig. 5. Lipid droplet associated with concentric rows of granular endoplasmic reticulum. Abbreviations: GC - Golgi complex; GER - granular endoplasmic reticulum; L - lipid droplets; M mitochondrion; $\mathrm{N}$ - nucleus; $\mathrm{Nu}$ - nucleolus; $\mathrm{SG}$ - shell globules; V - vesicles; I - immature vitellocyte; IIA - early stage of vitellocyte maturation; IIB - middle stage of vitellocyte maturation; IIC - advanced stage of vitellocyte maturation; III - mature vitellocyte. Scale bars: Fig. $1=4 \mu \mathrm{m}$; Figs. $2,3=1.5 \mu \mathrm{m}$; Figs. $4,5=0.3 \mu \mathrm{m}$. 

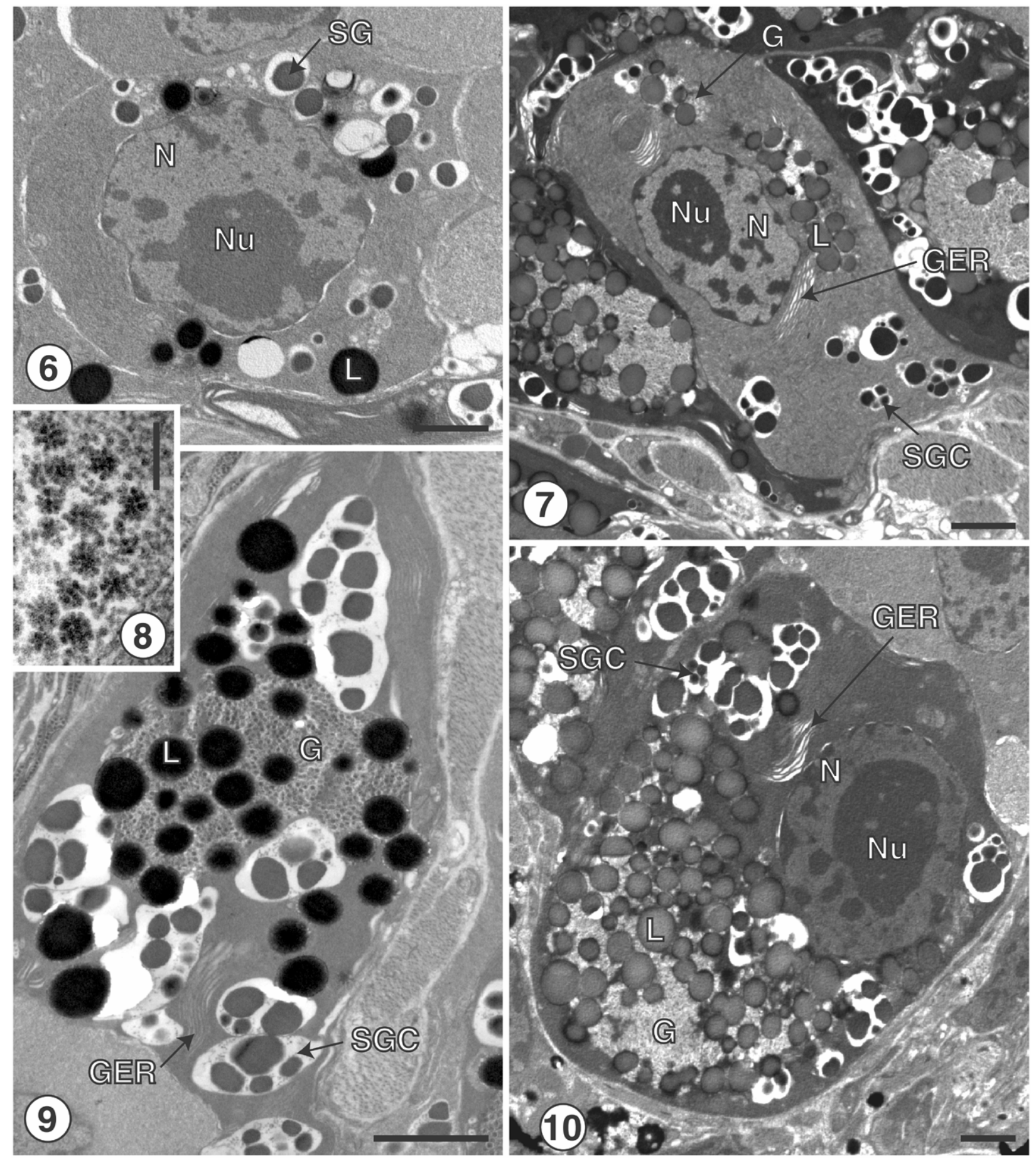

Figs. 6-10. Maturation stages and mature vitellocytes of Paraechinophallus japonicus. Fig. 6. Middle stage of vitellocyte maturation. Fig. 7. Advanced stage of vitellocyte maturation. Fig. 8. Rosettes of $\alpha$-glycogen stained with PA-TSC-SP. Fig. 9. Shell globule clusters, granular endoplasmic reticulum and lipid droplets associated with glycogen. Stained with PA-TSC-SP. Fig. 10. Mature vitelline cell. Abbreviations: $\mathrm{G}$ - glycogen; GER - granular endoplasmic reticulum; L - lipid droplets; $\mathrm{N}$ - nucleus; Nu nucleolus; SG - shell globules; SGC - shell globule clusters. Scale bars: Figs. 6, 7, 9, $10=2 \mu \mathrm{m}$; Fig. $8=0.2 \mu \mathrm{m}$.

1974, Korneva 2001). In P. japonicus, we subdivided the vitellocyte maturation into five stages: immature cell, three gradual stages of cell maturation, and mature vitellocytes. The first stage (immature cells) contains ribosomes and mitochondria in the cytoplasm. We con- sider the early and advanced phases of vitellocyte maturation described by Świderski and Xylander (2000) as three gradual stages: 1 - formation of the first shell globules and lipid droplets at the periphery of the cell cytoplasm; 2 - fullness of cytoplasm volume by single 

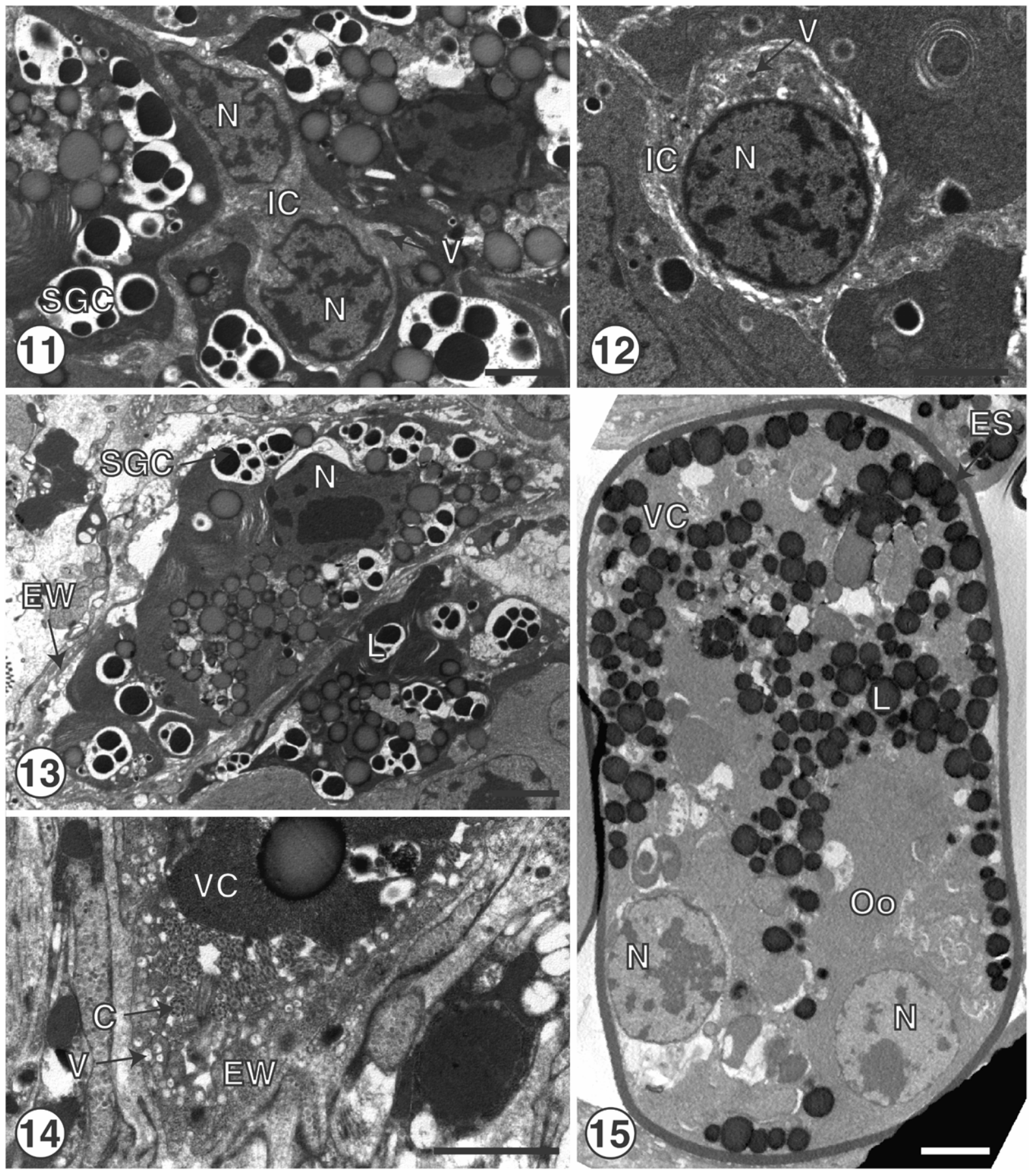

Figs. 11-15. Interstitial tissue, vitelline material within vitelline ducts and intrauterine eggs of Paraechinophallus japonicus. Fig. 11. Interstitial syncytium and cytoplasm of mature vitellocytes. Fig. 12. Nucleus of interstitial tissue and cytoplasmic projections of interstitial cytoplasm. Fig. 13. Vitellocyte within vitelline duct lumen. Fig. 14. Epithelial wall of vitelline duct. Fig. 15. Egg from uterine lumen. Abbreviations: C - cilia; ES - egg-shell; EW - epithelial wall; IC - interstitial cytoplasm; L - lipid droplets; N - nucleus; OO - oocyte; SGC - shell globule clusters; V - vesicles; VC - vitelline cytoplasm. Scale bars: Figs. 11, $12,14=1.5 \mu \mathrm{m}$; Figs. $13,15=2.5 \mu \mathrm{m}$.

shell globules and lipid droplets; 3 - formation of shell globule clusters and the presence of lipid droplets mixed with $\alpha$-glycogen. Mature vitelline cells of $P$. japonicus are characterized by the huge number of lipid droplets mixed with $\alpha$-glycogen, localized in the central cyto- plasm, whereas shell globule clusters are present in a more peripheral position.

In $P$. japonicus, all stages of vitellocyte maturation as well as vitellocytes within the lumen of the vitelline duct and vitelline cytoplasm of intrauterine eggs possess 


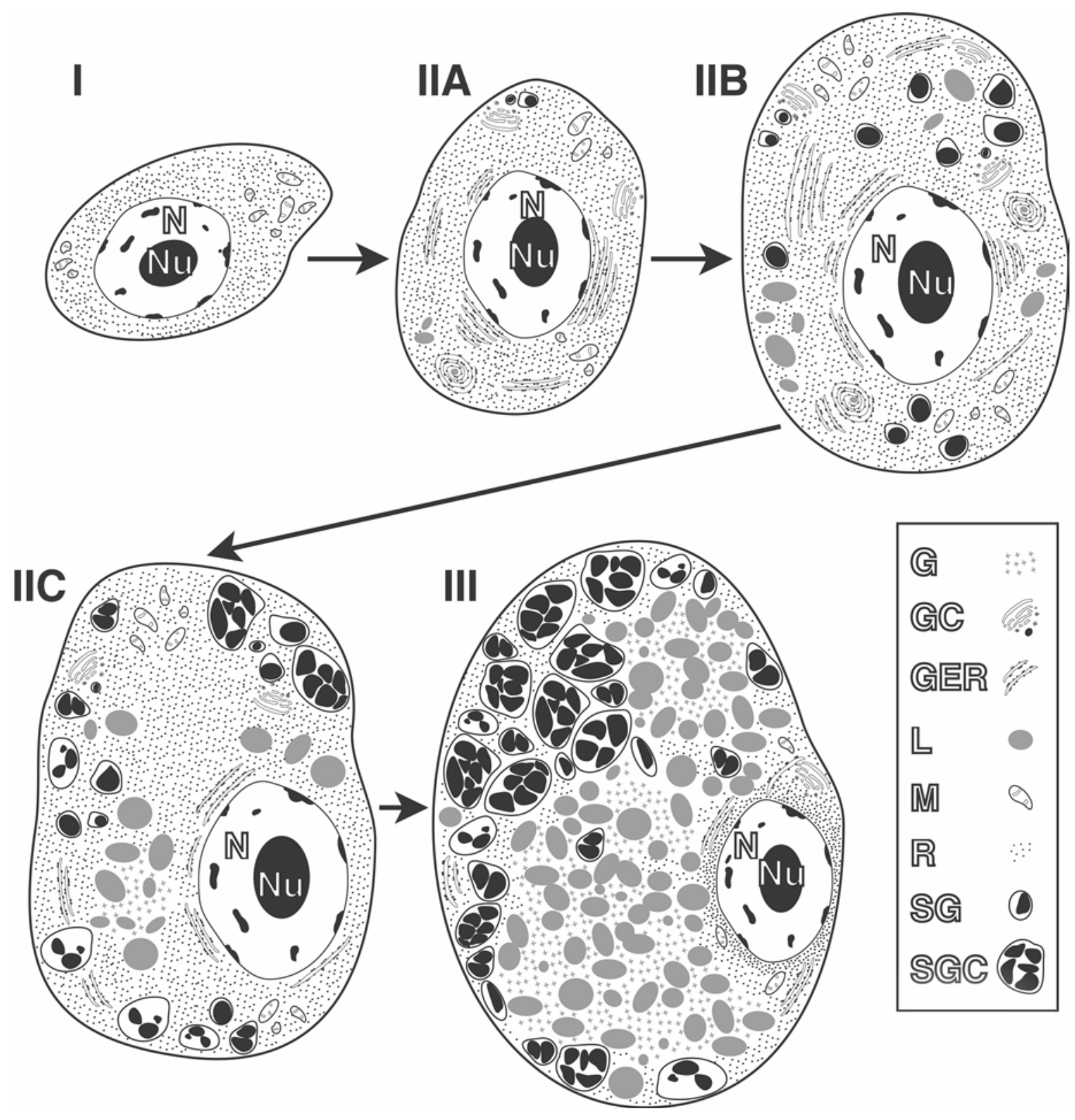

Fig. 16. Schematic diagram of development of vitelline cell of Paraechinophallus japonicus in vitelline follicles. I - immature cell; IIA - early stage of vitellocyte maturation; IIB - middle stage of vitellocyte maturation; IIC - advanced stage of vitellocyte maturation; III - mature cell. Abbreviations: G - glycogen; GC - Golgi complex; GER - granular endoplasmic reticulum; L lipid droplets; $\mathrm{M}$ - mitochondrion; $\mathrm{N}$ - nucleus; $\mathrm{Nu}$ - nucleolus; $\mathrm{R}$ - ribosomes; $\mathrm{SG}$ - shell globules; SGC - shell globule clusters.

nuclei with a nucleolus. Disappearance of the nucleus in the vitelloduct was reported in Amphilina foliacea by Xylander (1988), whereas the ultrastructure of vitellocytes does not change in the vitelloduct of the pseudophyllidean B. clavibothrium (Świderski and Mokhtar 1974).

The interstitial tissue of vitelline follicles of $P$. japonicus is syncytial and contains several nuclei and long cytoplasmic projections which extend between the vitelline cells. A syncytial structure of the interstitial tissue was also observed in the caryophyllidean Glaridacris catostomi (Świderski and Mackiewicz 1976) and in the pseudophyllidean T. nodulosus (Korneva 2001). In the spathebothriideans Cyathocephalus truncatus, Diplocotyle olrikii and Didymobothrium rudolphii, the interstitial syncytium contains a single nucleus in the centre of the follicle and two or three additional nuclei in the periphery (Bruňanská et al. 2005, Poddubnaya - unpubl. data).

Shell globule clusters in vitellocytes of $P$. japonicus consist of loosely packed shell globules situated in an electron-lucent matrix. Such arrangement of shell glob- 
ules is present in the most primitive tapeworms (Gyrocotylidea and Amphilinidea), but also in difossate groups of cestodes and basal tetrafossates, i.e. tetraphyllideans (Świderski and Mokhtar 1974, MokhtarMaamouri and Świderski 1976, Świderski and Mackiewicz 1976, Xylander 1987, 1988, Korneva 2001, Poddubnaya 2003, Poddubnaya et al. 2003, Świderski et al. 2004a, b, Bruňanská et al. 2005). On the other hand, tightly packed electron-dense globules combined with matrix of moderate electron density were observed in the caryophyllidean Caryophyllaeus laticeps, spathebothriideans $C$. truncatus and D. rudolphii and pseudophyllidean Diphyllobothrium latum (Świderski et al. 2004a, Bruňanská et al. 2005, Poddubnaya - unpubl. data). In the Cyclophyllidea, vitelline material consists of large vitelline vesicles (Świderski et al. 1970, 2005a, Świderski 1973).

Lipid droplets and glycogen serve as nutritive reserves for the future embryo (Świderski and Xylander 2000). In $P$. japonicus, only electron-dense lipid droplets containing a high level of unsaturated fatty acids are present in mature vitellocytes (Świderski and Xylander 2000), similarly as in D. olrikii (Bruňanská et al. 2005). Mature vitellocytes can also contain electron-lucent lipid droplets representing saturated fatty acids (Świderski and Xylander 2000), as observed in another pseudophyllidean B. clavibothrium (Świderski and Mokhtar 1974) and amphilinideans, gyrocotylideans, tetraphyllideans and proteocephalideans (Świderski et al. 1970, Mokhtar-Maamouri and Świderski 1976, Xylander 1987, 1988, Bruňanská 1997). The most evolved tapeworms, Cyclophyllidea, usually show no traces of lipid droplets (Świderski and Xylander 2000).

The presence of numerous lipid droplets in the cytoplasm of mature vitelline cells is a characteristic feature of vitellocytes of $P$. japonicus. High accumulation of lipid droplets in mature vitellocytes was reported in the tetraphyllidean Echeneibothrium beauchampi (MokhtarMaamouri and Świderski 1976), in the trypanorhynch Dollfusiella spinulifera and Progrillotia pastinacae (Świderski et al. 2006a, b), but also in the basal cestodes, i.e. Gyrocotylidea and Amphilinidea (Xylander 1987, 1988).

In the present study, lipid droplets, glycogen and shell globule clusters were observed in mature vitellocytes in vitelline ducts, whereas in intrauterine eggs only lipid droplets are dominating component of the vitelline cytoplasm. This observation indicates that shell globule clusters of vitelline cells were completely used during egg-shell formation in P. japonicus. Regarding the role of vitelline shell globules in pseudophyllidean tapeworms, it has been shown by Świderski and Mokhtar (1974) in B. clavibothrium that vitellocytes and Mehlis' gland products are involved in formation of electron-dense egg-shells. In the spathebothriidean $D$. olrikii, the initiation of shell formation around fertilized ovum and vitellocytes becomes apparent in the proximal part of the ootype. In this region, the vesicles of the ootype epithelium and vitelline cell cytoplasm are associated with newly formed nascent shells (Poddubnaya et al. 2005).

Vitelline inclusions, lipid droplets and glycogen as nutritive material supply developing embryo in the eggs (Świderski and Xylander 2000). The eggs of platyhelminths, which develop in external environment, utilize their nutrient supplies provided by vitelline cells. In some species, encapsulated eggs are retained in the uterus. The intrauterine egg development depends on the biology and ecology of transmission in helminths (Esch 1983). No data are available on whether or not the eggs of $P$. japonicus start their development inside or outside the uterus. However, this cestode possesses a well-developed uterine sac with lateral diverticles filled with numerous eggs (Protasova 1977). The presence of a uterine sac, where eggs continue their development, is established for the pseudophyllidean Eubothrium rugosum (Protasova 1977). Ultrastructural study of E. rugosum reveals numerous lipids droplets within eggs from uterine sac in this species (Poddubnaya 2003). In another ultrastructural and cytochemical studies on the eggs of closely related pseudophyllidean species $E u$ bothrium salvelini, Świderski et al. (2005b) also reported the presence of numerous large lipid droplets and glycogen both in normally developing and in mature eggs, as well as in nonviable abortive eggs accumulated in the uterus of this species. We may assume that the presence of a large amount of lipid droplets in the cytoplasm of vitelline cells within the eggs of $P$. japonicus probably depends on the egg accumulation into uterine sac. However, the life cycle of this cestode parasitic in a benthopelagic fish is not known and more data on its biology are necessary to confirm this assumption. We find also that future investigations into vitellocyte material of eggs of "lower" tapeworms with different degrees of oviparity are very important for understanding of cestode adaptations to different ways of egg transmission and development.

Acknowledgements. We are grateful to the staff of the Laboratory of Electron Microscopy, Institute of Parasitology AS $\mathrm{CR}$, České Budějovice, Czech Republic, for technical assistance. This study was supported by the Grant Agency of the Czech Republic (project nos. 206/03/1317 and 524/04/3342), research projects of the Institute of Parasitology, Academy of Sciences of the Czech Republic (Z60220518 and LC 522), and the Russian Foundation of Fundamental Researches (RFFI), grant no. 05-04-48250 to L.G.P. 


\section{REFERENCES}

BRUŇANSKÁ M. 1997: Proteocephalus exiguus La Rue, 1911 (Cestoda, Proteocephalidae): ultrastructure of the vitelline cells. Helminthologia 34: 9-13.

BRUŇANSKÁ M., PODDUBNAYA L.G., DEZFuli B.S. 2005: Vitellogenesis in two spathebothriidean cestodes. Parasitol. Res. 96: 390-397.

ESCH G.W. 1983: The population and community ecology of cestodes. In: P. Pappas and P. Arme (Eds.), The Biology of Cestodes. Academic Press, New York, pp. 81-138.

KORNEVA J.V. 2001: Vitellogenesis and capsule formation during embryogenesis in Triaenophorus nodulosus (Cestoda, Pseudophyllidea, Triaenophoridae). Zool. Zh. 80: 1422-1428. (In Russian.)

MOKHTAR-MAAMOURI F., ŚWIDERSKI Z. 1976: Vitellogenèse chez Echeneibothrium beauchampi Euzet, 1959 (Cestoda: Tetraphyllidea, Phyllobothriidae). Z. Parasitenkd. 50: 293302.

PODDUBNAYA L.G. 2003: Structure of the reproductive system of the amphicotylide cestode Eubothrium rugosum (Cestoda, Pseudophyllidea). J. Evol. Biochem. Physiol. 39: 345-355.

PodDuBnaya L.G., MACKIEWICZ J.S., KuPERMAN B.I. 2003: Ultrastructure of Archigetes sieboldi (Cestoda: Caryophyllidea): relationship between progenesis, development and evolution. Folia Parasitol. 50: 275-292.

PODDUBNAYA L.G., MACKIEWICZ J.S., ŚWIDERSKi Z., BRUŇANSKÁ M., SCHOLZ T. 2005: Fine structure of egg-forming complex ducts, eggshell formation and supporting neuronal plexus in progenetic Diplocotyle olrikii (Cestoda, Spathebothriidea). Acta Parasitol. 50: 292-304.

PROTASOVA E.N. 1977: [Bothriocephalata - Tapeworm Helminths of Fish. Essentials of Cestodology. Vol. 8.] Nauka, Moscow, 298 pp. (In Russian.)

REYNOLDS E.S. 1963: The use of lead citrate at high $\mathrm{pH}$ as an electron-opaque stain in electron microscopy. J. Cell Biol. 17: 208-212.

ŚWIDERSKI Z. 1973: Vitellogenesis in the cestode Inermicapsifer madagascariensis (Davaine, 1870) Baer, 1956. Proceedings of the 48th Annual Meeting of the American Society of Parasitologists, Toronto, p. 40.

ŚWIDERSKi Z., BRUŇANSKÁ M., MŁOCICKI D., CONN D.B. 2005b: Ultrastructure of the oncospheral envelopes in the pseudophyllidean cestode Eubothrium salvelini (Schrank, 1790). Acta Parasitol. 50: 312-318.

ŚWIDERSKI Z., BRUŇANSKÁ M., PODDUBNAYA L.G. 2004a: Ultrastructural and cytochemical studies on vitellogenesis in the caryophyllidean cestode Caryophyllaeus laticeps. Proceedings of the IX European Multicolloquium of Parasitology, Valencia, Spain, 18-23 July 2004, p. 602.

ŚWiderski Z., BRUŇANSKÁ M., PODDUBNAYA L.G., MACKIEWICZ J.S. 2004b: Cytochemical and ultrastructural study on vitellogenesis in caryophyllidean cestode Khawia armeniaca (Cholodkovski, 1915). Acta Parasitol. 49: 16-24.

ŚWIDERSKI Z., CHOMICZ L., GRYTNER-ZIECINA B., TKACH V.V. 2000: Electron microscope study on vitellogenesis in Catenotaenia pusilla (Goeze, 1782) (Cyclophyllidea, Catenotaeniidae). Acta Parasitol. 45: 83-88.

ŚWIDERSKI Z., HugGel H., SCHONENBERGER N. 1970: Comparative fine structure of vitelline cells in cyclophyllidean cestodes. Proceedings of the 7th International Congress on Electron Microscopy, Grenoble, pp. 825-826.

ŚWIDERSKI Z., MACKIEWICZ J.S. 1976: Electron microscope study of vitellogenesis in Glaridacris catostomi (Cestoidea: Caryophyllidea). Int. J. Parasitol. 6: 61-73.

ŚWIDERSKi Z., Miquel J., MŁocicki D., NeIFAR L., GRYTNERZIEÇINA B., MACKIEWICZ J.S. 2006a: Ultrastructural and cytochemical studies on vitellogenesis in trypanorhynch cestode Dollfusiella spinulifera Beveridge, Neifar et Euzet, 2004 (Eutetrarhynchidae). Acta Parasitol. 51: 182-193.

ŚWiderski Z., Miquel J., MŁOCICKI D., NeIfAR L., MaCKIEWICZ J.S. 2006b: Ultrastructure of vitellocytes in the cestode Progrillotia pastinacae Dollfus, 1946 (Trypanorhyncha, Progrillotiidae). Acta Parasitol. 51: 194-199.

ŚWIDERSKi Z., MŁociCKI D., EIRA C., MiQUel J., GRYTNERZIEÇINA B., MACKIEWICZ J.S. 2005a: Vitellogenesis in Mosgovoyia ctenoides (Railliet, 1980) Beveridge, 1978 (Cyclophyllidea, Anoplocephalidae). Acta Parasitol. 50: 305-311.

ŚWIDERSKI Z., MOKHTAR F. 1974: Etude de la vitellogénèse de Bothriocephalus clavibothrium Ariola, 1899 (Cestoda: Pseudophyllidea). Z. Parasitenkd. 43: 135-149.

ŚWIDERSKI Z., XYLANDER W.E.R. 1998: Types of vitellocytes and vitellogenesis in the Cestoda in relation to different types of embryonic development, ovoviviparity and life cycle. Wiad. Parazytol. 44: 604.

ŚWIDERSKI Z., XYLANDER W.E.R. 2000: Vitellocytes and vitellogenesis in cestodes in relation to embryonic development, egg production and life cycle. Int. J. Parasitol. 30: 805-817.

THIERY J.-P. 1967: Mise en évidence des polysaccharides sur coupes fines en microscopie électronique. J. Microsc. 6: $987-$ 1018.

XYLANDER W.E.R. 1987: Ultrastructural studies on the reproductive system of Gyrocotylidea and Amphilinidea (Cestoda). II. Vitellaria, vitellocyte development and vitelloduct of Gyrocotyle urna. Zoomorphology 107: 293-297.

XYLANDER W.E.R. 1988: Ultrastructural studies on the reproductive system of Gyrocotylidea and Amphilinidea (Cestoda). I. Vitellarium, vitellocyte development and vitelloduct in $\mathrm{Am}$ philina foliacea (Rudolphi, 1819). Parasitol. Res. 74: 363370 .

Accepted 12 September 2006 